\title{
Time Traveling in Delaware State Parks - Volunteer Labor is NOT Free Labor
}

\author{
John P McCarthy'* and Rachael A Marks \\ Department of Archaeologist/Architectural Historian, Delaware Div of Parks and Recreation DNREC-State Parks, USA
}

Submission: November 02, 2017; Published: December 06, 2017

*Corresponding author: John P McCarthy, Department of Archaeologist/Architectural Historian, DNREC-State Parks 152 S State St. Dover, De 1990, USA, Email: john.mccarthy@state.de.us

\section{Opinion}

Shortly after the senior author started working as Cultural Preservation Specialist with Delaware State Parks in the fall of 2014, his supervisor, Jim Hall, casually asked if he had told him about Time Travelers during the job interview. Somewhat warily, John replied that, no, he didn't think that been mentioned. Jim then said, in his usually breezy manner, that Time Travelers was the volunteer program that Parks used to have for archaeology, and that john would have to restart it. While panic was his initial response, on reflection, he began to see the potentials of a participatory public archaeology program, not only for Delaware State Parks but for the participants as well.

Much has been written recently about cultural heritage and engagement with community stakeholders, especially by archaeologists who feel that archaeology is a particularly effective tool for community engagement and empowerment. Archaeology has a powerful authenticity and objectivity, and it also offers the thrill of discovery along with sweat, dirt, bugs, and poison ivy. Engagement with the public though actual participation in the archaeological process in the field or laboratory is increasingly common and many research projects rely on some form of volunteer labor to meet goals and objectives. Additionally, archaeology as a discipline benefits from greater public awareness of the existence of archaeological resources, the ethics of preservation and active engagement to help protect resources, and engagement with the potential next generation of practioners.

John was very aware of the value of volunteers, having been one himself early in his career and having also worked with volunteers in some of his other positions before joining Delaware State Parks. While he had considerable respect for volunteers, he also had a certain disdain for the idea that archaeology was something State Parks could think that they did not have to pay to have performed on its behalf. After all, Parks did not engage "volunteer" engineers to design new restrooms or parking lots. That said, John saw a role for the interested public, under professional supervision, to assist with not only the smallscale regulatory compliance projects that the cultural resource program undertakes, but he also saw the potential for longerterm research initiatives as well. From the outset, however, Time Travelers was envisioned as primarily a program of outreach and enrichment, not of free labor.

It is a truism that volunteer labor is never free, but what is the cost of volunteer labor and how are they compensated? A volunteer is, by definition, someone who offers to undertake something in addition to their regular duties without additional compensation if they are an employee or someone from the pubic who performs some service without formal payment. Volunteers, in my experience, need a minimum of four things:

1) To have a worthwhile experience

2) Appropriate training

3) Effective supervision, and

4) The knowledge that their contributions of time and energy are recognized and valued. Ideally, the volunteer should get at least as much out of the experience as the agency gets in labor value.

In large part, volunteers are compensated though taking part in the process of discovery itself; by sharing the experience of all that is entailed in discovery. To a consumer, the difference between a cup of coffee at McDonalds that costs a $\$ 1$ and a cup of coffee at Starbucks that costs $\$ 4$ is the quality of the experience of ordering the beverage, its customization, and the setting of its consumption. Accordingly, we've made an effort to try to emphasize the goals and objectives of the projects in which I include volunteers.

While no experience is required to become a Time Traveler volunteer, informal and formal training are part of the program. The inexperienced are paired with a more experienced "buddy," and we were fortunate that the Time Traveler program was 
able to draw nearly immediately on a pool of experienced excavators active with the Archaeological Society of Delaware. A three-hour basic archaeology class was developed that all, even the previously experienced, are encouraged to attend. An embroidered Time Traveler logo patch is awarded to those who complete the class. Additional training on such topics as historic ceramics identification have been offered as well and others are in development.

Time Travelers are always supervised by a very experienced staff person, either John or his assistant, Rachael. Usually both are present, working closely with the volunteers, answering questions, offering encouragement, and getting down and dirty

This work is licensed under Creative Commons Attribution 4.0 Licens DOI: 10.19080/GJAA.2017.02.555588 ourselves. One should never ask or expect a volunteer to do work that you yourself are not willing to do and be seen doing.

Finally, Time Travelers are always thanked profusely for having come out, and those who participate in three programs are awarded their own trowel. We frequently have small gifts such as State Parks branded materials like travel mugs to distribute. Those who contribute 100 hours of effort in the year receive an annual park pass with a value of $\$ 35$.

We have tried to give our Time Traveler volunteers as much as we get from them. We currently have a mailing list of 48 people, and several thousand hours of effort are contributed to State Parks archaeology each year.

\section{Your next submission with Juniper Publishers will reach you the below assets}

- Quality Editorial service

- Swift Peer Review

- Reprints availability

- E-prints Service

- Manuscript Podcast for convenient understanding

- Global attainment for your research

- Manuscript accessibility in different formats

( Pdf, E-pub, Full Text, Audio)

- Unceasing customer service

Track the below URL for one-step submission https://juniperpublishers.com/online-submission.php 